\title{
The Pace and Stability of Small Enterprise Innovation in Highly Dynamic Economies: A China-Based Template *
}

\author{
by Xibao Li and Ronald K. Mitchell
}

In this paper we analyze the dynamics of knowledge-spillover entrepreneurship in the Chinese "transitional" context, as template for the evaluation of the pace and stability of small business innovation institutionalization in many transition economies; and we also provide theory and evidence to further develop knowledge spillover entrepreneurship theory. Based on the first available cross-sectional dataset (2005 for 2004) covering 158 manufacturing sectors over the five Chinese provinces representing one third of China's industrial output, the empirical analysis provides evidence that local competition / specialization affect the pace / stability of innovation institutionalization in SEs (small enterprises) and LMEs (large-medium enterprises) differentially, suggesting new insights for research and policy in the transition-economy / small business management context.

\section{Introduction}

Small business management is not what it used to be. The new "dynamic" view sees small businesses as agents of change (Audretsch 1995; Audretsch and Thurik, 2001), and suggests that "smallness" is a key contextual factor that matters to both researchers and policy-makers interested in innovation. In this sense entrepreneurship and its context are virtually inseparable (Venkataraman 1997). Knowledge spillover entrepreneurship theory (KSET) takes the inseparability of firm and context into account, suggesting that beyond prevailing theories of entrepreneurship which primarily focus on the ability of individuals to identify opportunity: contexts with more knowledge generate more entrepreneurial opportunities, and entrepreneurship is the conduit for the knowledge spillovers that make opportunities happen

\footnotetext{
${ }^{*}$ This article benefited greatly from the constructive and thoughtful comments of two anonymous reviewers, the Special Issue editor and participants in the fourth annual Office Depot research forum on Entrepreneurial Innovation and Technology Strategy, April 19, 2008, Fort Lauderdale, Florida. Xibao Li acknowledges the financial support provided by National Natural Science Foundation of China (Project No.: 70602005). Ronald K. Mitchell acknowledges the support from the Jean Austin Bagley Regents Chair Endowment in the Jerry S. Rawls College of Business at Texas Tech University.

Xibao Li is an assistant professor in the Department of Innovation and Entrepreneurship and Research Center for Technological Innovation at Tsinghua University, Beijing, China.

Ronald K. Mitchell is a Professor of Entrepreneurship, Rawls College of Business, Texas Tech University.

Address correspondence to: Xibao Li, School of Economics and Management, Tsinghua University, Beijing 100084, China. Tele: (8610) 62795443. Email: Lixibao@sem.tsinghua.edu.cn.
} 
(Audretsch and Keilbach 2007). KSET is especially relevant to small businesses in highly dynamic contexts where diffusion of knowledge results from agglomeration and/or specialization: the concentration and the mobility of highly-skilled labor (Audretsch and Keilbach 2007; Marshall 1920), and where as a result, the institutionalization of innovation within a given geographical region can vary in its pace of adoption and long-term stability, depending upon the firm context as determined by size: small versus large / medium enterprise.

Highly dynamic competitive contexts are likely to occur in transition economies, because of the inherent disequilibrium therein - suggesting that the term "transition" is becoming much more broadly defined. In the past, the definition of a transition economy has been limited to the situation where state-sponsored socialism, giving way to market capitalism, was unleashing the power of innovation-based entrepreneurship (Doh 2000; Mugler 2000; Peng 2001). However, it is now increasingly clear as dynamic economic transition processes mature - with an almost infinite variety of approaches emerging - that the term "transition" economy now applies more universally to any economy in which dynamism occurs in an Austrian economic sense: where disequilibrium is the norm, and where the capitalist / socialist poles on the dynamic continuum have now been replaced with lower or higher levels of market imperfection (Jacobsen 1992; Mitchell 2003). In this paper we therefore suggest that a careful analysis of the dynamics of knowledge-spillover entrepreneurship in the Chinese "transitional" context can be useful: (1) as template for the evaluation of the pace and stability (Lawrence, Winn, and Jennings 2001) of small business innovation in many similar contexts, and also (2) for proposing answers, in the small business setting, to normative questions about the import of theory and evidence for policy measures that actively encourage knowledge spillover entrepreneurship (Döring and Schnellenbach 2004).

The paper is organized as follows. We first provide a brief introduction to the theoretic framework and propose two hypotheses that flow from it. Then we describe model specifications, data, empirical strategies and measurement issues. Based on the empirical findings, we discuss implications for policy and for future research and finally conclude.

\section{Theoretical Framework and Hypotheses}

In highly dynamic contexts, the process whereby small businesses add value follows a predictable pathway toward the institutionalization of innovation. Lawrence, Winn, and Jennings (2001) suggest that the pace of institutionalization flows from objective factors (such as increasingly intensified competition), where very little personal "negotiation" is involved in, for example, information transfer; and that the stability of institutionalization flows from systemic factors (versus episodic), such as spillovers, which become embedded within a context, and

therefore do not require repeated activation. Innovation levels in regional economies can therefore become institutionalized in more or less stable, and also in more or less rapid ways, depending upon the factors that lead to knowledge dynamism among firms and the intensity of local competition, as depicted in Figure 1.

\{Insert Figure 1 about here\} 
However, in such a highly dynamic context, it remains an open question as to the impact that firm size should be expected to have on theoretical models and upon the normative policy questions that arise as a result. Figure 1 therefore illustrates the potential outcomes that depend upon pace and stability for their attributes. Empirical results interpreted through this lens can help scholars and policy makers to know what to expect in a given situation, and to have more lead time to consider what to do about it: essentially, to enable them to better evaluate the extent to which knowledge dynamism and competition will impact both the theory and practice of innovation in small business management.

The literature suggests that the construct which represents knowledge dynamism flow from KSET (Audretsch 1995; Audretsch and Keilbach 2007; Audretsch and Lehmann 2005; Marshall 1920). The main premise of KSET suggests that knowledge spillovers serve as the source of entrepreneurial opportunities for small and new firms and answer the question: How are firms with negligible R\&D able to generate innovative output (Audretsch 2005)? But as just noted, in a dynamic setting where both the knowledge and the context are variable (knowledge levels being dynamic, and the context being both increasingly competitive and enterprise-size sensitive), institutional questions concerning the pace of development, and the stability of the resulting factors supporting innovation (Lawrence, Winn, and Jennings 2001) must be addressed; and (as previously noted) such questions therefore require that notions of local competition also explicitly be included in the model. Otherwise, knowledge-based-only explanations suffer a similar disability to individual-differences-only based explanations for innovation, accounting for stability of the knowledge-transfer processes, but not for the pace of such transfers (which notably has been missing from the transition / highly dynamic-economy literature because it requires that levels of specialization and competition in a particular locale be captured cross-sectionally in an agglomerative context (Kesidou 2007)).

Herein we suggest that the pace of innovation institutionalization is affected through the mechanism of local competition, because the intensity of competition speeds up information and knowledge flows. We also argue that knowledge dynamism impacts occur through the mechanism of local specialization, based on the literature which suggests that higher specialization in a region makes knowledge spillover systemic versus episodic (Audretsch and Lehmann 2005). In this section we therefore set forth the elements of a local competition / specialization model that accounts for both pace and stability, and further set forth a limited institutional explanation that extends KSETespecially as it applies within a transitional / highly-dynamic economy context. Moreover, in order to shed light on the impact of firm size on theoretical models and facilitate the discussion of normative policy questions, we make an explicit comparison between SEs and LMEs and examine the pace and stability of innovation for each group separately (see Figure 2).

In section 2.2 we address localized specialization, and in Section 2.3, local competition. We also note that the model we propose (local to regional, Figure 2) is a cross-level one: an additive compositional model constructed according to the standards of multi-level analysis as suggested by Chan (1998).

\{Insert Figure 2 about here\} 


\section{Localized Specialization}

That knowledge spillovers promote innovation has long been recognized in the empirical literature. Jaffe (1989) and Audretsch and Feldman (1996) found that R\&D activities in large firms or universities can generate positive externalities via knowledge spillover. Jaffe, Trajtenberg, and Henson (1993) provide further evidence suggesting that these externalities are localized and bounded within the region where new economic knowledge was created. Besides these knowledge spillovers stemming from organized R\&D activities, economically valuable knowledge also flows between geographically co-localized firms in other ways. Long before the importance of in-house R\&D was acknowledged, and when referring to geographical agglomeration of industries, Marshall (1920) argued that localization economies in a geographically concentrated industry stem from both knowledge spillover among competitors and a pooling of specialized labor and suppliers created by industry demand. This thesis claims that knowledge spillovers mainly occur between firms within the same industry and emphasizes the importance of specialization externalities which are often noted as Marshall-Arrow-Romer (MAR) externalities in the literature (Glaeser, Kallal, Scheinkman, and Shleifer 1992). Similarly, Porter (1990) insists that knowledge spillovers within a specialized and geographically concentrated industry enhance productivity and stimulate growth. Thus, in the sense that specialization externalities are conducive to knowledge flows across firms, they also have the potential to promote innovation.

In the empirical literature, however, findings are mixed. For example, Feldman and Audretsch (1999) found that important technological knowledge spillovers are likely to occur between industries, rather than within industries in US metropolitan areas, thus lending no support to the MAR view. In contrast, Paci and Usai (1999), Greunz (2004) and van der Panne (2004) provide evidence supporting MAR externalities in European countries. These contrasting results lead us to observe that the impact of specialization on innovation seems to be contingent upon the context under investigation. Using a data set covering 20 two-digit manufacturing SIC sectors in 30 Chinese provinces, Li (2007) showed that the MAR specialization thesis holds on a larger geographical scale in a highly dynamic context. Thus by extrapolation we expect in a highly dynamic context that:

\section{H1a: Localized specialization has a positive impact on sector innovation outcomes by enterprise size.}

Previous empirical studies also provide ample evidence supporting the view that small firms are in a better position in terms of capturing external knowledge spillovers or technological externalities. Acs, Audretsch, and Feldman (1994) found that, although in-house R\&D has a relatively more important impact on innovative activity in large corporations than in small firms, small firms can innovate through exploiting knowledge created by expenditure on research in universities and R\&D in large corporations. In the case of clustering or agglomeration economies, Shaver and Flyer (2000) reached a similar conclusion. They argued that firms not only benefit from externalities, but also contribute to positive externalities. Relatively large firms, usually with better technologies, employees, and access to supporting industries, contribute more to and benefit less from agglomeration than small firms. In this sense, large firms suffer competitively from localization externalities when their advantages in technologies and human capital spill over to 
small competitors. Accordingly, we also expect in a highly dynamic context that:

H1b: The impact of localized specialization on sector innovation will be more favorable to SEs than to LMEs.

\section{Local Competition}

One motivation underlying this study is that the rapid increase of SEs in China during the past several years suggests that current LMEs have to compete with more SEs than ever before. We believe this is indicative of a transition disequilibrium context that is instructive beyond the China case. Given such a case, where there is a dynamic, agglomerative economy, one might ask, "Does such an intensified local competition speed up the introduction of firms' innovations?" The MAR thesis noted previously, argues that local monopoly allows technological externalities to be internalized and is thus more favorable to innovation than is local competition. Again, in contrast, Porter $(1990,1998)$ argued that ruthless competition among local competitors increases firms' pressure to innovate and fosters the introduction and adoption of innovation. In the US context, Feldman and Audretsch (1999) have provided empirical support for Porter's favorable view of local competition; and it would be helpful, we think, to check this in the transition / dynamic context as well.

At the firm level, local competition is a contributing element to this turbulent and dynamic organizational environment. Scholars in the field of strategic management and organizational present ample evidence that firms operating in a turbulent, highly uncertain, and dynamic environment are likely to be proactive in the face of competition (see, for example, Tan 2001; Tan 2006). Thornhill (2006), for example, demonstrated that industry-level dynamism is positively related to firm-level innovation and that firms in challenging competitive conditions are more innovative and entrepreneurial. In the Chinese context, Tan and Tan (2005) observed that contradictions between two opposing ideologies - a capitalist market-driven economic system and a socialist ideology - have produced additional energy and turbulence and a chaotic business environment that is particularly conducive to entrepreneurial activities. It is therefore expected that local competition will speed up the introduction of innovations by firms and have a favorable impact on the pace of innovation institutionalization in transition contexts. We suggest that in a highly dynamic context:

\section{H2a: Local competition has a positive impact on sector innovation outcomes by enterprise size.}

Additionally, the nature of competition-based size differentials is also of interest to both research and to policy-making practice. For example, Acs and Audretsch (1987) suggest three aspects of market structure that can be used to examine the relative innovative advantage of large versus small firms - size distribution, the existence of barriers to entry, and the stage of the industry in the product life cycle; and they report that small firms have the relative innovative advantage in a more competitive market than do large firms. In the case of Chinese small entrepreneurial firms, Tan (2001, p. 363) asserts that: "The small size and simple structure pre-positioned entrepreneurs for speed and surprise, giving them the ability to react quickly to opportunities in the environment 
or proactively outmaneuver the more established competitors." This sharp contrast in their strategic profile between LMEs and SEs bears on the innovation behaviors of each group, which suggests the following further hypothesis might be expected to apply in a highly dynamic context:

\section{H2b: The impact of local competition on sector innovation will be more favorable to SEs than to}

LMEs.

\section{Summary}

Our review of the literature suggests that to date, studies on the innovativeness of small enterprises are very rare in China in particular, and in the transitional context in general. Most of the empirical research in the Chinese context has examined only innovation activity contributed by LMEs (for example, $\mathrm{Hu}$ and Jefferson 2005). However, the findings and inferences drawn from such studies may be incomplete because, as we hypothesize (H1b, H2b), local specialization and competition are expected to be more conducive to the innovation within small enterprises than that within LMEs, and to impact differentially the pace and stability of the institutionalization of innovation practices. Therefore we reason that by additional analysis of the innovative activity of LMEs and SEs we will hopefully obtain a more complete story about the influence of localization externalities within KSET. We therefore turn to a description of the methodology we have employed to test our hypotheses.

\section{Methodology}

\section{Data}

In this paper we examine the importance of specialization and competition to the innovation of firms of different size in a transitional economic-sector context using the China case as a template. For this purpose, a region-industry combination is selected as the unit of analysis for the sector-level dependent variable. By substituting the domestic patent application counts from LMEs and SEs into an augmented knowledge production function, the disparate effect of technological externalities on innovation outputs of enterprises of different size can be compared. Accordingly, the analysis is based on a cross-sectional data set spanning 158 three-digit Chinese standard industrial classification (SIC) manufacturing sectors over five provincial-level regions in $2004^{1}$. The usage of census data is an obvious advantage of this analysis due to its relative objectivity and accessibility, as we further explain.

According to China's statistical practices, all state-owned enterprises and those non-state owned enterprises with annual sales over five million in RMB (about US\$750,000) are referred to as Above-Designated-Size-Enterprises (ADSE) ${ }^{2}$ thus excluding very tiny firms. ADSEs can be further categorized into two groups: LMEs and SEs. The demarcation between the LME and SE

\footnotetext{
${ }^{1}$ According to Chinese SIC, there are 169 three-digit SIC manufacturing sectors in total. Two industries, SIC 253(Nuclear Fuel) and SIC 424 (Nuclear Radioactive Material) are excluded due to data unavailability.

2 According to the first economic census data, about 20.1 percent enterprises belong to the ADSE category. They account for 90.7 percent of gross industrial output, 90.9 percent of sales, 89.5 percent of total assets, 97.5 percent of export value, and 71.2 percent of total industrial employment.
} 
categories is based on three criteria: employment, sales and assets. An ADSE is considered to be an SE if it has fewer than 300 employees $^{3}$, or its annual sales are less than 30 million RMB (about US\$4.5 million), or its total value of assets is less than 40 million RMB (about US\$6 million). Otherwise, it is considered to be an LME. In the China sense, SEs referred to in this analysis are "small" only relative to LMEs, since all ADSEs have annual sales exceeding five million RMB (about US\$750,000).

In 2005, the Chinese National Bureau of Statistics (CNBS) conducted its first economic census among all business establishments operating in China in 2004. In this census, firm-level information on innovation activities in 2004 was also collected from all ADSEs. To maintain the confidentiality of firm-level information and yet to make data publicly available, CNBS aggregated census data according to firm size and two-digit SIC sector, and published about 30 science and technology indicators in a series of economic census yearbooks including both the China Economic Census Yearbook and 31 province-level economic census yearbooks. From this data source, innovation indicators at a finer three-digit SIC level are either available or can be constructed for LME and SE groups in a few provinces.

For purposes of this analysis we include 167 three-digit SIC manufacturing sectors. Due to limitations on data availability, but consistent with our plan to capture highly dynamic agglomerative contexts, the data set was constructed mainly from the census yearbooks of five key provinces (Tianjin, Heilongjiang, Shanxi, Jiangsu and Guangdong), which represent the most comprehensive information so far available in the China context. Among these five provinces, Tianjin, Jiangsu and Guangdong belong to the Eastern Region of China, and the other two provinces are members of the Central Region of China ${ }^{5}$. As reported in Table 1, these five provinces account for about one third of all enterprises in China, and contribute one third of gross industrial output. In terms of employment, small enterprises in these regions provide more jobs than LMEs.

3 For comparison purposes, according to the US Small Business Administration (http://www.fedaccess.com/what-is-smallbusiness.htm, retrieved on June 24, 2008), a small business is defined (depending upon its attributes, in US\$) to be a business with:

- $\quad 500$ or fewer employees for most manufacturing and mining industries (a few industries permit up to 750, 1000 or 1,500 employees);

- 100 or fewer employees for all wholesale trade industries;

- $\quad \$ 6$ million per year in sales receipts for most retail and service industries (with some exceptions);

- $\quad \$ 27.5$ million per year in sales receipts for most general \& heavy construction industries;

- $\$ 11.5$ million per year in sales receipts for all special trade contractors;

- $\$ 0.5$ million per year in sales receipts for most agricultural, forestry and fishing industries.

${ }^{4}$ In the Guangdong province economic census yearbook, innovation indicators are available for both the LME and SE group. Information for the SE group in the other four provinces is constructed from ADSE and LME indicators which are reported in respective census yearbooks.

${ }^{5}$ According to the practice in CNBS, Chinese provinces are classified into three statistical tiers, namely, Eastern, Central and Western Regions, based on their economic development level. Eastern Regions in China include twelve provinces, namely, Beijing, Tianjin, Hebei, Liaoning, Shanghai, Jiangsu, Zhejiang, Fujian, Shandong, Guangdong, Guangxi, and Hainan. Central Regions include nine provinces: Shanxi, Neimenggu, Jilin, Heilongjiang, Henan, Hunan, Hubei, Jiangxi, and Anhui. The remaining 9 provinces are classified into the third tier Western Regions. From this perspective, a province in the Central Regions may not be located in the central part of China geographically. For instance, two provinces, Jilin and Heilongjiang, although classified in Central Regions, are actually located in the far northeast of China. The inclusion of only five regions in our date set may bring a selection bias into our estimation, which we do not think is serious because whether a region reports indicators at three-digit SIC is largely random. 
These sample characteristics make it highly useful with which to test our hypotheses in a credible context.

\section{\{Insert Table 1 about Here\}}

Because we operationalize the unit of analysis in this study as the three-digit SIC sector at the region (or province) level, and because a particular sector may not exist in some provinces, missing units are present in the constructed data set. In our data set, $248 \mathrm{LME}$ and $56 \mathrm{SE}$ units do not exist. In addition, there are $189 \mathrm{LME}$ and $325 \mathrm{SE}$ units that have not conducted any R\&D activities. In order to compare innovation performance between LME and SE groups, we want to focus on those units which were at least R\&D performers. Thus, after dropping non-existent and non-R\&D-performing region-industry units in each size group, 398 and 454 observations are left for further examination in the LME and SE groups, respectively, which span 158 of the total of 167 three-digit SIC manufacturing sectors. At a higher aggregation level, a two-digit SIC sector distribution of observations is presented in Table A1 in the Appendix.

\section{The Empirical Model}

As noted, to assess the impact of local specialization and competition on innovation activity, we use the count of domestic patent applications as the major measure of innovation outcomes. Considering the non-negative and discreteness feature of patent counts, a cross-sectional count data model is considered to be appropriate according to the following logic: Let $y_{i j}$ be the number of patent applications filed by region $i$ and industry $j$. Drawing upon previous studies on R\&D-patent relationships (for example, Pakes and Griliches 1984; Hall, Griliches, and Hausman 1986; Hall and Ziedonis 2001), an augmented innovation function may be specified as follows:

$$
E\left(y_{i j}\right)=\exp \left(\begin{array}{l}
\alpha_{0}+\alpha_{1} \operatorname{Ln}\left(R D_{i j}\right)+\alpha_{2} \delta_{\left\{S 1_{i j}=0\right\}}+\alpha_{3} \operatorname{Ln}\left(S P 1_{i j}\right)+\alpha_{4} \operatorname{Ln}\left(S P 2_{i j}\right)+\alpha_{5} S P E C_{i j} \\
+\alpha_{6} C O M P_{i j}+\alpha_{7} \delta_{\left\{S_{i j}=0\right\}}+\alpha_{8} \operatorname{Ln}\left(K S_{i j}\right)+\alpha_{9} \operatorname{Ln}\left(N O_{i j}\right)+\sum_{i} \beta_{i} D R_{i}
\end{array}\right) .
$$

Here, $R D_{i j}$ is the contemporaneous $\mathrm{R} \& \mathrm{D}$ expenditures performed by either the LME group or the $\mathrm{SE}$ group in industry $j$ within region $i$. $S P 1_{i j}$ reflects $R \& D$ spillovers from the other enterprise group in the same industry within the same region. That is, if the dependent variable $y_{i j}$ is referred to the LME (or SE) group, $S P 1_{i j}$ will be contemporaneous R\&D expenditures by SE (or LME) group. The dummy variable $\delta_{\left\{\left.S\right|_{i j}=0\right\}}$ is included to address the case where only one group of enterprises exists in some units. This variable takes a value of 1 if $S P 1_{i j}$ is zero and a value of 0 otherwise. $S P 2_{i j}$ is the industry-level $R \& D$ expenditures in China minus $R D_{i j}$ and represents R\&D spillovers from ADSEs operating in the same industry but located in other regions of China ${ }^{6}$. SPEC $i j$ and $C O M P_{i j}$ are measures of specialization externalities and local competition, respectively. $K S_{i j}$ represents the knowledge (or patent) stock of industry $j$ in region $i$, which is measured by the

${ }^{6}$ Ideally, spillover is best directly measured by patent citation of one group of firms from another. In the Chinese domestic patent system, however, no patent citation information is available. Accordingly, our measure of R\&D spillover should be regarded as a rough proxy. 
number of effective invention patent grants owned by an enterprise group. $\quad \delta_{\left\{K S_{i j}=0\right\}}$ is a dummy variable which equals 1 if $K S_{i j}$ is zero, and is 0 otherwise. $N O_{i j}$ is the number of enterprises in each group. $D R_{i}$ represents the four region dummies.

R\&D expenditures are usually persistent and highly correlated over time; but previous studies have found that the association between $R \& D$ expenditure and patent production exists only at the contemporaneous level (see, for example, Hall, Griliches, and Hausman 1986). Thus, in specification (1), only current R\&D expenditure is included. Results reported in Jaffe (1989), Jaffe, Trajtenberg, and Henderson (1993), and Audretsch and Feldman (1996) suggest that R\&D activities generate knowledge spillovers and positive externalities, which represent only a part of dynamic localization economies stemming from specialization or agglomeration. To control for R\&D externalities explicitly, we incorporate both $S P 1_{i j}$ and $S P 2_{i j}$ in equation (1). Also, as an indication of a high degree of unit heterogeneity, the over-dispersion of patent counts calls for special econometric treatment in the estimation. Unit heterogeneity may result from the variation across both industries and regions. Industries are different in technology opportunity and nature of technology, and regions are heterogeneous in size, geographical location and economic status. To account for industry heterogeneity, both previously-granted invention patents and the number of enterprises are incorporated in the model. Region dummies are included to alleviate the effect of region heterogeneity and, if any, systematic differences between regions in terms of geographic agglomeration. By estimating equation (1) for the innovation contributed by LMEs and SEs separately, and directly comparing the magnitude of the coefficient SPEC and COMP, the relative importance of localized specialization and competition can be explicitly ascertained.

Because the count of patent applications is highly skewed and contains many zero observations, as shown below, the usual Poisson regression does not seem appropriate. Special econometric techniques are again needed to take into consideration specific features of such dependent variables. In practice, mean-dispersion negative binomial regressions, so-called NB2 regressions (Cameron and Trivedi, 1998; Winkelmann, 2000), deal with the over-dispersion issue in a parametric way, but cannot accommodate excess zeros. To manage excess zero observations, we follow the strategy developed by Lambert (1992) and assume that zero observations in the data come from two different data generating processes: units that do not engage in innovation activities at all, and those units that do innovate but fail to generate patentable innovations ${ }^{7}$. This treatment allows us to distinguish the two types of zeros, which seems reasonable, according to the following logic.

To get an idea of how two zero-generating processes are modeled explicitly and separately, let us assume that one group of units is innovating and the other is non-innovating. Let the likelihood of a unit being non-innovating be $p_{i j}$; and the probability of a unit being innovating $1-p_{i j}$. With probability $p_{i j}$, a unit's patent count is zero; with probability $1-p_{i j}$, the patent count is drawn from a negative binomial count data generating process. The full model can therefore be specified as:

\footnotetext{
${ }^{7}$ It should be pointed out that, although all units in our data set invested in R\&D, some of them may not be innovating in the sense of generating new knowledge. As Cohen and Levinthal (1989) pointed out, R\&D has dual functions. A firm conducts R\&D activities not only for generating new knowledge (that is, innovation), but also for developing absorptive capacity (that is, learning). Forbes and Wield (2000) argued that the learning function of R\&D is particularly important in technology follower countries.
} 


$$
P\left(y_{i j}\right)=\left\{\begin{array}{ll}
p_{i j}+\left[1-p_{i j}\right] f_{2}(0) & \text { if } y_{i j}=0 \\
{\left[1-p_{i j}\right] f_{2}\left(y_{i j}\right)} & \text { if } y_{i j}>0
\end{array},\right.
$$

where $f_{2}$ is a negative binomial density which mean function can be defined as in (1), and $p_{i j}$ is modeled as a Logit function of the unit's characteristics:

$$
\begin{aligned}
& p_{i j}=1 /\left[1+\exp \left(-z_{i j}\right)\right], \text { where } \\
& \qquad \begin{aligned}
z_{i j} & =\omega_{0}+\omega_{1} \delta_{\left\{S P 1_{i j}=0\right\}}+\omega_{2} \operatorname{Ln}\left(S P 1_{i j}\right)+\omega_{3} \operatorname{Ln}\left(S P 2_{i j}\right)+\omega_{4} S P E C_{i j} \\
& +\omega_{5} C O M P_{i j}+\omega_{6} \delta_{\left\{K S_{i j}=0\right\}}+\omega_{6} \operatorname{Ln}\left(K S_{i j}\right)+\omega_{7} \operatorname{Ln}\left(N O_{i j}\right)
\end{aligned} .
\end{aligned}
$$

Here, all variables are defined as in (1). Because $R \& D$ expenditures can be taken as a strategic choice of innovating, $R D_{i j}$ is excluded from (3). Due to computational problems, region dummies are also excluded from $(3)^{8}$. The estimation of this model can then proceed according to the usual maximum likelihood techniques. Specifically, in the estimation of the next section, zero inflated negative binomial (ZINB) models are employed (Cameron and Trivedi 1998; Crépon and Duguet 1997; Winkelmann 2000).

To check the robustness of estimations based on patent counts we therefore also consider two other measures: the percentage of total new product value (NPV) or new product sales (NPS) contributed by SEs in a region-industry unit. This is a necessary cross-check on the credibility of using patent data as a proxy for innovation outcomes according to the following reasoning. First, patent counts measure at best an intermediate output in the entire process of innovation. That is, not all patents are innovations, and not all innovations can be patented (Griliches 1990). Second, patents cannot reflect the economic importance of different innovations. In a transitional economy where intellectual property rights are less effectively protected, this difficulty could be magnified. Firms may therefore prefer to protect their R\&D achievements in other ways, rather than by filing a patent. Third, given the fact that some firms may not be patenting, one might wonder whether we are analyzing a phenomenon too early in its development. The resulting smallness of the patent number may render the coefficient estimates too noisy and unreliable. Hence we suggest the need to check the robustness of estimations based on patent counts. The model of SE shares that we use for this check is specified as follows:

$$
\begin{aligned}
N P V_{i j}\left(\text { or } N P S_{i j}\right) & =\lambda_{0}+\lambda_{1} S P E C_{i j}+\lambda_{2} C O M P_{i j}+\lambda_{3} \operatorname{Ln}\left(\operatorname{INTEN}_{i j}\right) \\
& +\lambda_{4} \delta_{\left\{K S_{i j}=0\right\}}+\lambda_{5} \operatorname{Ln}\left(K S_{i j}\right)+\lambda_{6} \operatorname{Ln}\left(S C A L E_{i j}\right)+\sum_{i} \eta_{i} D R_{i},
\end{aligned}
$$

where the dependent variable $N P V_{i j}$ (or $N P S_{i j}$ ) refers to SE share of new product value (or sales). INTEN $N_{i j}$ is the unit-level R\&D intensity defined by the ratio of R\&D expenditure to industrial output value. This variable is incorporated in the model to take into account the technological sophistication in a sector. $S C A L E_{i j}$ represents the unit-level industrial output value and is added to control for the industry size in a particular region. These share regressions are restricted to units in which both LME and SE group are present, which leads to a smaller sample. In this analysis, they

${ }^{8}$ When four region dummies are added into specification (3), regression results remain almost the same as those reported in first two
columns in Table (5) and (6), except that the regression of invention patent counts for SE group encounters a convergence problem. 
are estimated with Tobit regression techniques because some units have no new products registered at all, which results in a lower truncation at zero; and others have all products designated as new, which results in an upper truncation at 1.

\section{Measurement}

Due to data limitations, in this study we use the number of domestic patent applications as one indicator of innovation outcomes ${ }^{9}$. In the Chinese patent system, patents are classified into three types: inventions, utility models, and designs. With regard to economic value and technological importance these are very different across the three types. In the Chinese context, inventions represent "new-to-the-world" technological solutions and are technologically most innovative. Utility models are less sophisticated than inventions from a technological viewpoint, but are nonetheless "new-to-the-country." Designs reflect novelty in exterior features and, accordingly, contain the least new technological content. Given the remarkable difference in patent quality across these three categories, we do not deem it to be appropriate to take the count of total patent applications as a measure of innovation. Fortunately, the constructed data set contains information concerning both the number of total patent applications and of invention applications. A combined count of utility model and design (UMDE) applications can then be obtained by subtracting the latter from the former. In this analysis we therefore consider two measures of innovation output, the count of invention applications representing the most technologically intensive innovations, and the combined count of utility model and design application reflecting minor technological changes.

Following previous empirical work (for example, Glaeser, Kallal, Scheinkman, and Shleifer 1992; Greunz 2004; Feldman and Audretsch 1999; Paci and Usai 1999), our analysis uses a production specialization index based on employment data to proxy MAR externalities. Specifically, the localized specialization of an industry within a region is measured by the fraction of employment that this industry contributes in this particular region, relative to the share of the whole industry in nationwide employment:

$$
S P E C_{i j}=\frac{E M P_{i j} / \sum_{j=1}^{167} E M P_{i j}}{\sum_{i=1}^{30} E M P_{i j} / \sum_{j=1}^{167} \sum_{i=1}^{30} E M P_{i j}},
$$

where $E M P_{i j}$ is the total employment of industry $j$ in region $i$. This variable reflects the extent to which a region $i$ is specialized in industry $j$ relative to what one would expect if employment in industry $j$ were randomly distributed across the country. A larger value of $S P E C_{i j}$ implies a greater degree of specialization of industry $j$ in region $i$. Following the approach suggested by Paci and Usai (1999), a monotonic transformation: $\left(S P E C_{i j}-1\right) /\left(S P E C_{i j}+1\right)$ is used to standardize this original index so that it falls into the interval $(-1,1)$.

As developed in Glaeser, Kallal, Scheinkman, and Shleifer (1992), the measure of local competition of an industry within a region is constructed as the number of firms per worker in this

9 Although how to measure innovation has been the subject of a heated debate in innovation literature (Acs, Anselin, and Varga 2002; Hagedoorn and Cloodt 2003; Lanjouw and Schankerman 2004), due to its availability and reliability, patent data still remains one of the most popular measures of innovation in empirical literature. 
industry within this particular region relative to the number of firms per worker in this industry in the whole of China:

$$
C O M P_{i j}=\frac{N U M_{i j} / E M P_{i j}}{\sum_{i=1}^{30} N U M_{i j} / \sum_{i=1}^{30} E M P_{i j}},
$$

where $N U M_{i j}$ is the number of firms in industry $j$ of region $i$. A value of greater than one means that industry $j$ within region $i$ is locally more competitive than it is elsewhere in China. Again, it is standardized similar to the above transformation so that it is constrained within the interval $(-1,1)$.

Because the production specialization index and the measure of local competition are industry-level variables, they are not different for each enterprise group. Hence, $S P E C_{i j}$ and $C O M P_{i j}$, are constructed with firm-level information of all ADSEs necessitating the use of a cross-level additive composition model (Chan 1998, p. 236). These variables reflect the composition of economic activities at the region-industry level.

\section{Descriptive Statistics}

The correlation matrix and summary statistics of all variables are presented in Tables 2 and 3 . Although there are high correlations between some independent variables, an examination of values of Variance Inflation Factors (VIF) suggests that the issue of multicollinearity is not of serious concern. For count regressions, the average VIF values are 2.37 and 2.73 for LME and SE groups, respectively. For share regression, the average VIF value is 1.56. Note that, as can be observed clearly in Table 2, most Chinese industries are not high in patent production: the number of patent applications in each region-industry combination is quite small in magnitude. For example, the median of invention applications is only 1 for all region-industry combinations. Even when considering the number of utility model and design applications, a mean value of 2 is also regarded as small. Moreover, the distributions of the two measures of innovation output are over-dispersed and highly-skewed with variances much larger than means. This indicates that a high degree of heterogeneity exists across units. Table 4 gives more detailed information about the distribution of patent application counts. It can be seen that about 46 percent of LME and SE units do not file invention patents. In the case of less-technologically-sophisticated utility models and designs, there are about 37 percent of LME units and 45 percent of SE units having no patent filings. Accordingly, it appears that there are excessive zero observations in the sample. Thus, if the patent count is to be used as a dependent variable measurement in the empirical estimation, one has to take into account three specific features: (1) smallness, (2) over-dispersion, and (3) excess zeros, each of which calls for special attention in the empirical analysis. We report this special attention and our results in the following section.

\section{\{Insert Tables 2, 3, and 4 about Here\}}

\section{Results}

\section{Hypothesis Tests}


Because Poisson models are nested within NB2 models, the usual likelihood tests can be used to evaluate these two types of models. In this study, NB2 models are always found to be preferred to Poisson models, which is not surprising given the large over-dispersion present in the patent counts. The selection between NB2 and ZINB models can be based on the Vuong test (Vuong 1989). For all specifications in this analysis, it is found that Vuong tests always favor ZINB models ${ }^{10}$, suggesting that excess zeros may actually come from the two different sources as previously noted. Using the count of invention applications as the measure of innovative outputs, we present results from count regressions in Table 5.

\section{\{Insert Table 5 about Here\}}

Column (1) of Table 5 reports the estimated results from the ZINB regression of invention applications for the LME group. It can be observed that the estimated coefficient of SPEC is positive and statistically insignificant $(p>.05)$, while the estimated coefficient of COMP is negative and statistically significant. We infer from this that the fierce competition of an industry within a region is not favorable to innovation activities in LMEs. When all non-patenting units are ignored, a Zero-Truncated Negative Binomial (ZINB) model can be estimated for those patenting units ${ }^{11}$. Estimated results provided in column (2) tell a similar story as that obtained from the ZINB estimates. Thus, a coherent conclusion emerges from these two regressions. That is, local competition hinders innovation activity by LMEs, while the impact of specialization is unclear for LMEs.

The estimation for the SE group follows a similar process, the results of which, however, are different from what are obtained for the LME group. Regardless of whether non-patenting units are taken into account, the estimated coefficients of SPEC from two count regressions provided in column (3) and (4) are both significant and positive, indicating that SEs are benefiting from localized specialization of an industry. In view of the small and insignificant coefficients of SPEC in the LME case, we suggest both hypotheses $\mathrm{H} 1 \mathrm{a}$ and $\mathrm{H} 1 \mathrm{~b}$ are weakly supported. Although statistically insignificant, the coefficients of COMP are found to positive for the SE group, suggesting that local competition may be favorable to innovation of SEs. Compared with the significant negative sign of COMP coefficients in the LME group, these consistent results suggest that hypothesis $\mathrm{H} 2 \mathrm{a}$ is weakly supported for SEs and not supported for LMEs. Contrasting results between SEs and LMEs not only suggest that $\mathrm{H} 2 \mathrm{~b}$ is supported but also reveal an interesting observation. That is, LMEs operating in a highly dynamic transition economy may become less proactive in the face of more intensified completion. In a transitional economy like China, LMEs are usually older and rooted more deeply in the old non-market regime. Unlike newly emerged SEs, these firms have inherently different values and incentive mechanisms, and therefore are not just big grown-up SEs (for example, Welsch and White 1981). In terms of ownership structure and entrepreneurial orientation, one may argue that recently founded SEs in China share many common

10 Because zero-inflated Poisson (ZIP) models are nested within ZINB models, the likelihood tests show that ZINBs are much better than ZIPs in all specifications of this analysis.

11 Zero-Truncated Poisson (ZTP) models are special cases of ZTNB models. The likelihood tests show that ZTNBs are preferred to ZTPs in all specifications. 
characteristics with their counterparts in mature market economies. However, the same argument is unlikely to be true when applied to LMEs. To some extent, the difference between capitalism and socialism is partially embodied in the form of size differentials or firm heterogeneity in China. Therefore, previous findings from mature economies must be qualified when applied to transitional economies like China. This actually strengthens our argument implicated in $\mathrm{H} 2 \mathrm{~b}$ that competition-based size differentials are prominent in China.

As expected, the estimated coefficients of $\operatorname{Ln}(R \& D)$ are positive and statistically significant in both specifications for the LME group, suggesting the importance of intentional innovation activities (that is, R\&D). This holds true for the SE group in the ZTNB estimation. When non-patenting SE units are ignored, however, the coefficient of $\operatorname{Ln}(R \& D)$ becomes insignificant. In contrast to the coefficient of SPEC, this result seems to suggest that knowledge spillovers within industry are more effective than $R \& D$ in facilitating innovation in patenting $S E$ units. The coefficients of $\operatorname{Ln}(K S)$ are found to be significant and positive in two cases (for both LMEs and SEs), which demonstrates an important influence of a previous knowledge stock on innovation outputs. Somewhat surprisingly, direct intra-industry R\&D spillovers from the counterpart group within the region and ADSEs in other regions are found to be insignificant for both LMEs and SEs, no matter which specification is estimated. Given the relative importance of local specialization for the SE groups, these results suggest that SEs gain important intra-industry knowledge spillovers from LMEs mainly through non-R\&D channels.

Similar estimation strategies are adopted for regressions of utility model and design applications, the results of which are provided in Table 6. For the LME group, regardless of whether non-patenting units are excluded, neither the estimated coefficients of SPEC nor those of COMP are significant in the two types of regressions used. Accordingly, it seems clear to us that the production of UMDE applications by LMEs is not significantly affected by the local composition of economic activities. In the case of the SE group, the coefficients of SPEC are significant and positive in both estimations listed in columns (3) and (4). The same is true for the coefficient of COMP. This suggests that geographical specialization and local competition within an industry are conducive to innovation by SEs in terms of UMDE patent applications. These results lend further support to hypotheses $\mathrm{H} 1 \mathrm{~b}$ and $\mathrm{H} 2 \mathrm{~b}$.

\section{\{Insert Table 6 about Here\}}

In comparison with results reported in Table 5, the importance of both SPEC and COMP for innovation activity of SEs seems to be strengthened in the production of UMDE applications. It indicates that the role of local specialization and competition are more influential in fostering the less sophisticated technological innovation in SEs. We also note that estimated coefficients for other variables are quite similar to those given in Table 5. One interesting observation is that the coefficients of $\operatorname{Ln}(R \& D)$ are insignificant when only patenting SE units are considered in two ZTNB cases (see column 4 in Table 5 and Table 6). That is, no matter whether invention or UMDE count is taken as a measure of innovation output, the importance of in-house R\&D for SE's innovation is rather limited when compared to inter-firm knowledge spillovers within industries. 


\section{\{Insert Table 7 about Here\}}

Results from two share regressions are reported in Table 7, which confirm what has been found in the count regression models. Both local specialization and competition enhance the relative advantage of SEs in terms of new product production and sales. This amounts to an additional validation for hypotheses $\mathrm{H} 1 \mathrm{~b}$ and $\mathrm{H} 2 \mathrm{~b}$. The estimated coefficient of $\operatorname{Ln}($ INTEN) is negative and statistically significant, suggesting that in those industries where R\&D investment is intensive, small firms are not in a favorable position to introduce new products. This result is both consistent with our intuition and with the findings in Acs, Audretsch, and Feldman (1994). Finally, although $L n(K S)$ is insignificant in both regressions, the negative sign of $\operatorname{Ln}(S C A L E)$ is consistent with the results reported in Acs and Audretsch (1987).

\section{Limitations}

We recognize several limitations in the interpretation of our results. The first, concerns one complication in testing for specialization externalities: that is, whether a high concentration in a local economy really measures dynamic localized economies. Because innovation rates may also affect the agglomeration of enterprises, these results must be somewhat qualified. As argued by Feldman (1999), if some mature industries have large-scale production facilities dominating certain locations, a high concentration of an industry in a particular region may be just a measure of production specialization and not of dynamic localization economies. Therefore, based on the analysis of cross-sectional data, it is difficult to entirely capture the dynamic relationship among specialization, competition and innovation, which may be worthy of exploring in the future with, for example, a panel data set covering multiple years' observations. In addition, previous research normally has investigated the phenomenon of local specialization and competition at the city or cluster level. Given the relatively large size of Chinese provinces and the somewhat arbitrary region definitions, one may argue that the rationale underlying specialization externalities and/or agglomeration economies may be stretched too much to be applicable. Therefore, another topic for future research would be to explore a similar issue at a cluster level. Finally, we suggest that the issue addressed herein should be further dimensionalized by analysis at the firm level, which should reveal more about innovation dynamics in an increasingly specialized and competitive business environment.

\section{Discussion and Conclusion}

\section{Discussion}

Ever since Griliches (1979) formalized a model of the firm knowledge production function, the traditional view of knowledge and innovation has been that firms exist exogenously, and then invest in $R \& D$ to endogenously create new knowledge and ideas. However, when small firms were consistently found to contribute more to innovative output than might be expected from their relatively low investments in R\&D, KSET (Audretsch, 1995) was introduced to resolve the apparent contradiction with the notion-now well-supported in the literature- that entrepreneurship is also 
an endogenous response to the potential for commercializing knowledge that has not been adequately commercialized by universities, incumbent firms, and so on, and applies to regions in addition to national and international clusters (Audretsch and Lehmann 2005). In this paper we have therefore carefully analyzed the dynamics of KSET in the Chinese "transitional" context as both a template for the evaluation of the pace and stability (Lawrence, Winn, and Jennings 2001) of small business innovation in many similar contexts, and also to better understand policy measures that actively encourage knowledge spillover entrepreneurship. Our results have implications for policy and for future research.

Implications for Policy: Open questions for practitioners are now tending to focus on policy issues at the more local level, especially those that concern the pace and stability of innovation in transition (highly dynamic agglomerative) contexts. This study provides early outlines and suggestions of such policies for: (1) the (competition-driven) pace, and (2) the (knowledge-spillover/specialization-driven) stability of innovation in a transition-economy firm-size context. Based on the disparate results reported above for LME and SE groups, one can conclude that small enterprises can benefit from regional knowledge spillovers within industries more favorably than can LMEs. Local specialization of an industry encourages SEs to engage in innovation activities at various technological levels. Competition is favorable to innovation in SEs too, but its importance is more prominent in less-technologically-sophisticated innovations as measured by UMDE patents, suggesting that SEs outperform their competitors mainly by introducing low-quality innovation. This finding is reasonable because it is usually more costly and risky for SEs to engaging in radical innovation, given their limited complementary resources. These results suggest that intense competition and high specialization in the China SE case (a high-agglomeration, highly dynamic knowledge-spillover transition-economy context) produce high-pace, high-stability institutionalization processes for small enterprises.

When mapped on Figure 1, the policy implications of these temporal dynamics can be imputed. Lawrence, Winn, and Jennings (2001) suggest that very fast-paced highly stable institutionalization will implicate force-based institutionalization process combined with domination-based processes. Such force-based processes are expected to be episodic in nature within a sector; and an example might include the failure of businesses that are unable to effectively avail themselves of knowledge-spillover-based specialization. Policies in transition contexts should therefore work toward lowering the cost of exit (for example, bankruptcy laws that preserve and re-cycle specialization). Domination-based processes are expected to reward actors which can effectively compete in material technologies (these material technologies need not be high-tech), or which use isolating mechanisms (Rumelt 1987) or increasing-returns economies (Arthur 1994) to control their market space. An example might include actors able to invoke and sustain what we term "success-mover" advantages - not necessarily being first movers, but possessing factors that effectively dominate the sector. Policy implications might include programs that enable the stabilization of the fast-movers within a region. Ready access to capital, for example, will be critical (for example, the development of viable public equity markets for efficient investor entry and exit).

In the case of LMEs, however, our results suggest that their innovation activities would be 
discouraged by fierce local competition. How increasing specialization would influence their innovation remains unclear. Thus, our findings suggest that geographical specialization and competition may actually harm innovation in large enterprises. In terms of the pace and stability model (Figure 1), we are therefore less able to impute expected outcomes; but still several likely observations appear to be relevant (Lawrence, Winn, and Jennings 2001). First, any continuation of LME attempts to function in Figure 1, Quadrant " $D$ " (the domain of the SEs) would appear to be unwise. And given that fierce local competition would tend to dampen LME innovation, it appears to be logical that LME policy (both exogenous and endogenous) should encourage movement away from fierce local competition toward markets where size is an advantage (for example, Quadrants " $\mathrm{A}$ " or " $\mathrm{B}$ " where influence or discipline-based institutionalization processes would favor LMEs), and where the rewards are sufficient to support continued R\&D. LME, for example, favors episodic impacts that can coerce or manipulate markets, and systemic impacts where norm-setting (for example, standardization of quality or of product specifications) can create market-expectation-based discipline that rewards innovation despite spillovers. In this respect we suggest that LMEs become more entrepreneurial, but focus such attention upon behaviors that will pay off; as we discuss in the next section.

Implications for Research: Consistent with the argument by Arrow (1962), we find that when the knowledge generated by large firms' $R \& D$ is exploited by small competitors who have not shared the costs of $R \& D$, large firms may be tempted to under-invest in $R \& D$. In the long run, the innovation in both large and small firms will therefore be harmed, unless large firms become more entrepreneurial, or small firms make more contributions to innovation. Accordingly, we explore further the following question: Given the same composition of economic activities (or industrial context) within a region, why is there a differential impact on LMEs and SEs? Winter (1984, pp. 297) suggests that in innovation, large firms respond to the technological and economic environment quite differently from small firms, which is also compatible with findings in Acs and Audretsch (1988). He speculated that there exist two possible technological regimes, "An entrepreneurial regime is one that is favorable to innovative entry and unfavorable to innovative activities by established firms; a routine regime is one in which the conditions are the other way around." The favorable impact of industrial context for SEs in this analysis suggests that an entrepreneurial regime is likely to be the case in most sectors. In the Chinese case, because most industries are in a catching-up stage, and are evolving during the transition process, routine regimes are as yet unlikely in many industries.

Accordingly, to examine the composition of the SE group - to ascertain the nature of these small firms, with attributes relevant to research - we note at least four distinguishing features: ownership type, the size-age link, reaction times, and scale economies. First, in the Chinese context, Tan (2001) observed that firm size is probably a surrogate for ownership type, which has significant association with entrepreneurial and strategic orientation. He found that entrepreneurs from small privately-owned enterprises adopt a quite different strategic orientation from managers of large state-owned enterprises. For example, they have stronger motivation to innovate and are more proactive and willing to make risky decisions. Second, firm size may be associated with the age of firms. Due to its transitional characteristics, it can be postulated that many small firms in 
the Chinese economic context are young startups with a relatively short history. By contrast, large firms are more likely to be older and deeply rooted in the previous paradigm. Therefore, they may not be as able to transform themselves successfully (Zajac, Kraatz, and Bresser 2000). This argument was empirically confirmed by Tan (2007) who found that, even among state-owned enterprises, firms founded after 1990 are more innovative and more willing to take risk. Third, given their strong entrepreneurial approach, small firms can react more quickly to business opportunities than large established firms. Specialization and vertical disintegration may bring about some unfulfilled niches. Being more sensitive to unmet demand rising from those fringe markets, small firms are more likely to counteract the adverse effect of competition in the main market segment where large firms operate. Fourth, as an industry becomes locally specialized, the availability of a pool of skilled labor and specialized suppliers provides small firms with an opportunity to benefit from scale economies (Porter 1998), which also helps to enhance the relative advantage of small firms in innovation.

The findings in this analysis lend support for the MAR view in the debate on the importance of MAR externalities, that local specialization facilitates the introduction of innovation, and knowledge spillovers occurring within industries helps innovation. These findings are consistent with the conclusion in Paci and Usai (1999) and Greunz (2004), but differ from those in Glaeser, Kallal, Scheinkman, and Shleifer (1992) and Feldeman and Audretsch (1999). We speculate that differences may be due to the transitional context, since in more mature industries, the index of SPEC captures geographic specialization, not dynamic location economies (Feldman 1999); but this hypothesis is still in need of further research. Regarding the effect of local competition, our results for SEs support the view of Porter (1990) that local competition speeds up innovation. For LMEs, however, such an effect seems to be reversed. In this sense, we fully acknowledge that this study is only a beginning point in addressing size-based contextual questions in the literature.

\section{Conclusion}

Small business management is not what it used to be. It is more - as the China case illustrates in a transition economy context - broadly construed. This is because the increasing concentration and specialization of Chinese industries in Eastern regions suggests that a more general transitional context is at work: the surge of small enterprises simply exacerbating competition.

We have therefore explored the question: "How would the geographical specialization of industries and increasing competition influence the pace and stability of innovation institutionalization by enterprises of different size?" as a way to better understand the observation that the innovation activity of large firms and small firms responds differently to technological and economic environments. For small enterprises, both industrial specialization and competition within a region are conducive to innovation and therefore support the new dynamic view of small businesses as agents of change. For large and medium enterprises, however, increasing local competition is found to be detrimental to technologically sophisticated innovation, and suggests that a somewhat sophisticated entrepreneurial regime be employed. Therefore in highly dynamic agglomerative contexts, an innovation policy designed to simply support the development of core industries or industry clusters may be favorable to rapid and stable innovation institutions among entrepreneurial SEs in the shorter term, but unfavorable to the pace of LME innovation over the 
longer run. If not managed properly, the institutionalization of small business innovation practices may discourage R\&D investment within the large firms that are a key source of spillover knowledge, and thus harm both social and private interests in the long term. From a firm strategic point of view, large firms therefore need to become more entrepreneurial and proactive to counterbalance the dissipating effects of intense competition on specialization spillovers. Small firms can benefit from specialization externalities in a sustainable way by engaging in $R \& D$ and contributing to new technological knowledge. Thus as the dynamic view suggests: in transition economies, small business management and innovation management now go hand-in-hand. 
Table 1

Geographical Distribution of Chinese Industrial Enterprises in 2004

\begin{tabular}{|c|c|c|c|c|c|c|c|c|c|}
\hline & \multicolumn{3}{|c|}{ Number of Enterprises } & \multicolumn{3}{|c|}{$\begin{array}{l}\text { Industrial Output } \\
\text { (Billion RMB) }\end{array}$} & \multicolumn{3}{|c|}{$\begin{array}{c}\text { Employees } \\
\text { (Million) }\end{array}$} \\
\hline & ADSE & LME & SE & ADSE & LME & SE & ADSE & LME & SE \\
\hline China (Total) & 276474 & 27692 & 248782 & 20172.22 & 13337.47 & 6834.75 & 66.22 & 35.08 & 31.14 \\
\hline Proportion in Eastern Regions & 0.75 & 0.69 & 0.75 & 0.74 & 0.72 & 0.79 & 0.67 & 0.59 & 0.75 \\
\hline Proportion in 5 Provinces & 0.33 & 0.32 & 0.33 & 0.34 & 0.35 & 0.34 & 0.33 & 0.26 & 0.40 \\
\hline
\end{tabular}

Source: National Bureau of Statistics of China (2006). 
Table 2

\section{Correlation Matrix and Summary Statistics for Variables in Count Regressions}

\begin{tabular}{|c|c|c|c|c|c|c|c|c|c|c|c|}
\hline Variable & Invention & $\begin{array}{c}2 \\
\text { UMDE }\end{array}$ & $\begin{array}{c}3 \\
\operatorname{Ln}(R \& D)\end{array}$ & $\begin{array}{c}4 \\
\text { Dummy } \\
\text { SP1 }\end{array}$ & $\begin{array}{c}5 \\
\operatorname{Ln}(S P 1)\end{array}$ & $\begin{array}{c}6 \\
\operatorname{Ln}(S P 2)\end{array}$ & $\begin{array}{c}7 \\
\text { Dummy } \\
\text { KS }\end{array}$ & $\begin{array}{c}8 \\
\operatorname{Ln}(K S)\end{array}$ & $\begin{array}{c}9 \\
\operatorname{Ln}(N O)\end{array}$ & $\begin{array}{c}10 \\
\text { SPEC }\end{array}$ & $\begin{array}{c}11 \\
\text { COMP }\end{array}$ \\
\hline \multicolumn{12}{|c|}{ LME Group $(N=398)$} \\
\hline 2 & $0.246^{\star *}$ & & & & & & & & & & \\
\hline 3 & $0.197^{* *}$ & $0.297^{\star *}$ & & & & & & & & & \\
\hline 4 & -0.055 & -0.117 & $-0.267^{\star *}$ & & & & & & & & \\
\hline 5 & 0.096 & $0.218^{\star *}$ & $0.440^{\star *}$ & $-0.849 * *$ & & & & & & & \\
\hline 6 & $0.141^{\star *}$ & $0.156^{\star \star}$ & $0.412^{\star *}$ & -0.083 & $0.148^{\star \star}$ & & & & & & \\
\hline 7 & -0.091 & $-0.176^{\star \star}$ & $-0.356^{\star *}$ & $0.253^{\star *}$ & $-0.349^{\star \star}$ & $-0.250 * *$ & & & & & \\
\hline 8 & $0.263^{\star \star}$ & $0.399 * \star$ & $0.468^{\star \star}$ & $-0.277^{\star *}$ & $0.449 * \star$ & $0.271^{\star \star}$ & $-0.659 * *$ & & & & \\
\hline 9 & 0.094 & $0.319^{\star *}$ & $0.530^{* *}$ & $-0.436^{\star *}$ & $0.549^{\star \star}$ & $0.188^{\star \star}$ & $-0.374^{* *}$ & $0.503^{\star *}$ & & & \\
\hline 10 & 0.067 & $0.149^{\star \star}$ & $0.184^{\star *}$ & -0.075 & 0.084 & $-0.106^{*}$ & $-0.127^{*}$ & $0.188^{\star *}$ & $0.306^{\star \star}$ & & \\
\hline 11 & -0.053 & -0.028 & 0.053 & $-0.252^{\star \star}$ & $0.292^{\star \star}$ & 0.037 & -0.017 & -0.011 & 0.065 & $-0.466^{\star \star}$ & \\
\hline Mean & 17.193 & 22.216 & 6.950 & 0.229 & 4.682 & 10.456 & 0.430 & 1.118 & 2.146 & -0.015 & -0.019 \\
\hline Median & 1 & 2 & 7.325 & 0 & 5.543 & 10.638 & 0 & 0 & 2.079 & 0.015 & 0.015 \\
\hline S.D. & 159.514 & 91.155 & 2.250 & 0.420 & 3.005 & 1.480 & 0.496 & 1.475 & 1.245 & 0.372 & 0.237 \\
\hline \multicolumn{12}{|c|}{ SE Group $(N=454)$} \\
\hline 2 & $0.353^{\star \star}$ & & & & & & & & & & \\
\hline 3 & $0.399 * \star$ & $0.409 \star \star$ & & & & & & & & & \\
\hline 4 & $-0.204^{\star *}$ & $-0.233^{\star \star}$ & $-0.375^{\star \star}$ & & & & & & & & \\
\hline 5 & $0.291^{\star \star}$ & $0.336^{\star \star}$ & $0.505^{\star *}$ & $-0.885^{\star \star}$ & & & & & & & \\
\hline 6 & $0.115^{\star}$ & $0.110^{*}$ & $0.243^{\star *}$ & $-0.329 * \star$ & $0.449^{\star \star}$ & & & & & & \\
\hline 7 & $-0.345^{\star \star}$ & $-0.307^{\star \star}$ & $-0.477^{\star *}$ & 0.167 & $-0.243^{\star *}$ & $-0.133^{\star \star}$ & & & & & \\
\hline 8 & $0.608^{* *}$ & $0.586^{\star \star}$ & $0.555^{\star *}$ & $-0.274^{\star \star}$ & $0.402^{\star \star}$ & $0.196^{* *}$ & $-0.663^{\star *}$ & & & & \\
\hline 9 & $0.349 * \star$ & $0.410^{\star \star}$ & $0.527^{\star \star \star}$ & $-0.466^{\star \star}$ & $0.540^{\star \star}$ & $0.105^{\star}$ & $-0.355^{\star \star}$ & $0.467^{\star *}$ & & & \\
\hline 10 & $0.160^{* \star}$ & $0.200^{* *}$ & $0.161^{\star *}$ & $-0.275^{\star \star}$ & $0.305^{\star \star}$ & -0.073 & $-0.107^{\star}$ & $0.147^{\star *}$ & $0.350^{\star *}$ & & \\
\hline 11 & -0.037 & -0.047 & 0.038 & $0.220^{\star \star}$ & $-0.189 \star \star$ & 0.032 & -0.002 & 0.007 & -0.057 & $-0.563^{\star \star}$ & \\
\hline Mean & 3.764 & 11.231 & 5.58 & 0.324 & 4.92 & 10.159 & 0.432 & 0.963 & 4.136 & -0.074 & 0.049 \\
\hline Median & 1 & 1 & 5.795 & 0 & 6.103 & 10.245 & 0 & 0 & 4.151 & -0.053 & 0.057 \\
\hline S.D. & 9.061 & 26.453 & 1.89 & 0.468 & 3.851 & 1.599 & 0.496 & 1.266 & 1.45 & 0.387 & 0.234 \\
\hline
\end{tabular}

\footnotetext{
* $p<0.05$; *夫 $p<0.01$.
} 
Table 3

Correlation Matrix and Summary Statistics for Variables in Share Regressions

\begin{tabular}{|c|c|c|c|c|c|c|c|c|}
\hline Variables & $\begin{array}{c}1 \\
S N P V\end{array}$ & $\begin{array}{c}2 \\
\text { SNPS }\end{array}$ & $\begin{array}{c}3 \\
\text { SPEC }\end{array}$ & $\begin{array}{c}4 \\
\text { COMP }\end{array}$ & $\begin{array}{c}5 \\
\operatorname{Ln}(I N T E N)\end{array}$ & $\begin{array}{c}6 \\
\text { Dummy KS }\end{array}$ & $\begin{array}{c}7 \\
\operatorname{Ln}(K S)\end{array}$ & $\begin{array}{c}8 \\
\operatorname{Ln}(S C A L E)\end{array}$ \\
\hline 2 & $0.973^{\star *}$ & & & & & & & \\
\hline 3 & $-0.110^{*}$ & $-0.119^{\star}$ & & & & & & \\
\hline 4 & $0.168^{\star \star}$ & $0.162^{\star \star}$ & $-0.479 * \star$ & & & & & \\
\hline 5 & $-0.287^{\star \star}$ & $-0.302^{\star \star}$ & 0.015 & -0.007 & & & & \\
\hline 6 & 0.060 & 0.070 & $-0.090^{*}$ & -0.030 & -0.140 ** & & & \\
\hline 7 & $-0.132^{\star \star}$ & $-0.141^{* *}$ & 0.160 ** & 0.039 & $0.248^{\star \star}$ & $-0.608^{\star *}$ & & \\
\hline 8 & $-0.193^{\star \star}$ & $-0.194^{\star *}$ & $0.260^{* *}$ & 0.087 & -0.051 & $-0.367^{\star *}$ & $0.531^{* *}$ & \\
\hline Mean & 0.368 & 0.367 & -0.031 & -0.006 & -1.336 & 0.301 & 1.476 & 12.936 \\
\hline S.D. & 0.382 & 0.384 & 0.370 & 0.231 & 1.634 & 0.459 & 1.596 & 1.537 \\
\hline Number & 465 & 463 & 465 & 465 & 465 & 465 & 465 & 465 \\
\hline
\end{tabular}

* $p<0.05 ;{ }^{* \star} p<0.01$. 
Table 4

Distribution of Patent Application Counts

\begin{tabular}{|c|c|c|c|c|c|c|c|c|}
\hline \multirow{3}{*}{ Category } & \multicolumn{4}{|c|}{ LME Group } & \multicolumn{4}{|c|}{ SE Group } \\
\hline & \multicolumn{2}{|c|}{ Inventions } & \multicolumn{2}{|c|}{ UMDEs } & \multicolumn{2}{|c|}{ Inventions } & \multicolumn{2}{|c|}{ UMDEs } \\
\hline & Number & Percent & Number & Percent & Number & Percent & Number & Percent \\
\hline 0 & 183 & 45.98 & 146 & 36.68 & 211 & 46.48 & 203 & 44.71 \\
\hline $1-10$ & 158 & 39.70 & 130 & 32.66 & 199 & 43.83 & 151 & 33.26 \\
\hline $11-100$ & 52 & 13.07 & 105 & 26.38 & 43 & 9.47 & 88 & 19.38 \\
\hline $101-1000$ & 3 & 0.75 & 16 & 4.02 & 1 & 0.22 & 12 & 2.64 \\
\hline$>1000$ & 2 & 0.50 & 1 & 0.25 & & & & \\
\hline Total & 398 & 100 & 398 & 100 & 454 & 100 & 454 & 100 \\
\hline
\end{tabular}

Source: National Bureau of Statistics of China (2006). 
Table 5

Results from Count Data Regressions of Invention Patent Applications

\begin{tabular}{|c|c|c|c|c|c|c|}
\hline & \multicolumn{3}{|c|}{ LME Group } & \multicolumn{3}{|c|}{ SE Group } \\
\hline & \multicolumn{2}{|c|}{ ZINB } & \multirow[t]{2}{*}{ ZTNB } & \multicolumn{2}{|c|}{ ZINB } & \multirow[t]{2}{*}{ ZTNB } \\
\hline & Invention & Inflate & & Invention & Inflate & \\
\hline & (1) & & (2) & (3) & & (4) \\
\hline \multirow[t]{2}{*}{$\operatorname{Ln}(R \& D)$} & $0.198^{\star \star}$ & & $0.240^{\star *}$ & $0.149^{* *}$ & & 0.076 \\
\hline & (3.36) & & (3.09) & $(2.86)$ & & $(1.31)$ \\
\hline \multirow[t]{2}{*}{ Dummy SP1 } & -0.857 & -1.658 & -1.177 & 0.061 & -1.032 & -0.102 \\
\hline & $(1.73)$ & (1.18) & $(1.94)$ & $(0.24)$ & $(0.72)$ & $(0.33)$ \\
\hline \multirow[t]{2}{*}{$\operatorname{Ln}(S P 1)$} & -0.029 & -0.166 & -0.051 & -0.027 & -0.117 & -0.039 \\
\hline & $(0.45)$ & $(0.72)$ & $(0.68)$ & $(0.74)$ & $(0.56)$ & $(0.90)$ \\
\hline \multirow[t]{2}{*}{$\operatorname{Ln}(S P 2)$} & 0.028 & -0.216 & -0.059 & 0.058 & 0.036 & 0.106 \\
\hline & $(0.27)$ & $(1.08)$ & $(0.45)$ & $(0.87)$ & $(0.15)$ & $(1.53)$ \\
\hline \multirow[t]{2}{*}{ SPEC } & 0.305 & -0.905 & 0.092 & $0.632^{*}$ & 0.495 & $0.737^{*}$ \\
\hline & $(0.83)$ & $(0.99)$ & $(0.21)$ & $(2.21)$ & $(0.56)$ & $(2.38)$ \\
\hline \multirow[t]{2}{*}{ COMP } & $-1.571^{\star \star}$ & -0.179 & $-1.865^{\star \star}$ & 0.189 & 0.923 & 0.170 \\
\hline & (3.04) & $(0.13)$ & (2.92) & $(0.41)$ & $(0.61)$ & $(0.32)$ \\
\hline \multirow[t]{2}{*}{ Dummy KS } & 0.223 & $16.329 * \star$ & 0.777 & $-0.680^{*}$ & $16.372^{\star \star}$ & -0.458 \\
\hline & $(0.63)$ & $(32.60)$ & (1.90) & $(-2.09)$ & $(19.80)$ & $(1.53)$ \\
\hline \multirow[t]{2}{*}{$\operatorname{Ln}(K S)$} & $0.699 * *$ & $-13.239 * *$ & $0.857^{\star *}$ & $0.561^{\star *}$ & $-15.343^{\star \star}$ & $0.655^{\star *}$ \\
\hline & (7.94) & $(3.49)$ & $(7.92)$ & (8.17) & $(5.74)$ & $(8.46)$ \\
\hline \multirow[t]{2}{*}{$\operatorname{Ln}(N O)$} & -0.016 & -0.171 & 0.067 & 0.000 & -0.406 & -0.038 \\
\hline & $(0.15)$ & $(0.62)$ & $(0.53)$ & $(0.006)$ & $(1.38)$ & $(0.56)$ \\
\hline Number & 398 & 398 & 215 & 454 & 454 & 243 \\
\hline
\end{tabular}

Coefficients for constant terms and region dummies not reported for brevity; Robust $z$ Scores (absolute values) in parentheses; ${ }^{*} p<0.01,{ }^{*} p<0.05$. 
Table 6

Results from Count Data Regressions of UMDE Patent Applications

\begin{tabular}{|c|c|c|c|c|c|c|}
\hline & \multicolumn{3}{|c|}{ LME Group } & \multicolumn{3}{|c|}{ SE Group } \\
\hline & \multicolumn{2}{|c|}{ ZINB } & \multirow[t]{2}{*}{ ZTNB } & \multicolumn{2}{|c|}{ ZINB } & \multirow[t]{2}{*}{ ZTNB } \\
\hline & UMDE & Inflate & & UMDE & Inflate & \\
\hline & (1) & & (2) & (3) & & (4) \\
\hline \multirow[t]{2}{*}{$\operatorname{Ln}(R \& D)$} & $0.184^{\star *}$ & & $0.150^{*}$ & $0.189 * *$ & & 0.140 \\
\hline & (3.10) & & $(2.28)$ & (2.58) & & (1.89) \\
\hline \multirow[t]{2}{*}{ Dummy SP1 } & -0.831 & $-2.188^{\star}$ & -0.631 & 0.344 & 0.984 & 0.306 \\
\hline & $(1.71)$ & $(2.41)$ & $(1.25)$ & $(0.77)$ & $(0.90)$ & $(0.64)$ \\
\hline \multirow[t]{2}{*}{$\operatorname{Ln}(S P 1)$} & -0.003 & $-0.423^{\star *}$ & 0.002 & -0.007 & -0.111 & -0.010 \\
\hline & $(0.038)$ & (3.21) & $(0.029)$ & $(0.11)$ & $(0.74)$ & $(0.14)$ \\
\hline \multirow[t]{2}{*}{$\operatorname{Ln}(S P 2)$} & -0.105 & $-0.459 * *$ & -0.076 & 0.021 & $0.310^{*}$ & 0.040 \\
\hline & (1.06) & $(2.62)$ & $(0.79)$ & $(0.27)$ & $(2.08)$ & $(0.45)$ \\
\hline \multirow[t]{2}{*}{ SPEC } & 0.298 & -0.330 & 0.418 & $1.100^{\star *}$ & 0.598 & $1.063^{* *}$ \\
\hline & $(0.73)$ & $(0.43)$ & $(0.98)$ & $(2.81)$ & $(0.90)$ & $(2.67)$ \\
\hline \multirow[t]{2}{*}{ COMP } & -1.055 & -0.427 & -0.778 & $1.547^{\star \star}$ & -0.381 & $1.517^{*}$ \\
\hline & $(1.91)$ & $(0.33)$ & $(1.35)$ & $(2.60)$ & $(0.42)$ & (2.39) \\
\hline \multirow[t]{2}{*}{ Dummy KS } & 0.385 & $1.922^{*}$ & 0.379 & $0.669 *$ & $1.907^{\star *}$ & $0.674^{*}$ \\
\hline & (1.39) & (2.04) & (1.33) & $(2.20)$ & $(2.72)$ & $(2.27)$ \\
\hline \multirow[t]{2}{*}{$\operatorname{Ln}(K S)$} & $0.343^{\star \star}$ & -0.300 & $0.333^{\star \star}$ & $0.531^{\star \star}$ & -1.716 & 0.530 ** \\
\hline & $(4.77)$ & $(0.88)$ & $(4.43)$ & (5.54) & $(1.84)$ & (5.58) \\
\hline \multirow[t]{2}{*}{$\operatorname{Ln}(N O)$} & 0.248 & -0.278 & 0.261 & 0.166 & -0.125 & 0.194 \\
\hline & $(1.92)$ & (1.11) & (1.88) & (1.27) & $(0.50)$ & (1.47) \\
\hline Number & 398 & 398 & 252 & 454 & 454 & 251 \\
\hline
\end{tabular}

Coefficients for constant terms and region dummies not reported for brevity; Robust $z$ Scores (absolute values) in parentheses;

${ }^{\star *} p<0.01,{ }^{*} p<0.05$. 
Table 7

Results from Tobit Regressions of Small-Enterprise New Product Shares

\begin{tabular}{|c|c|c|c|c|}
\hline \multirow[b]{2}{*}{ Variables } & \multicolumn{2}{|c|}{ New Product Value Share } & \multicolumn{2}{|c|}{ New Product Sales Share } \\
\hline & $\boldsymbol{b}$ & $\begin{array}{c}\text { Robust t statistics } \\
\text { (Absolute Value) }\end{array}$ & $\boldsymbol{b}$ & $\begin{array}{l}\text { Robust t statistics } \\
\text { (Absolute Value) }\end{array}$ \\
\hline SPEC & $0.200^{*}$ & 2.37 & $0.178^{*}$ & 2.11 \\
\hline COMP & $0.518^{\star \star}$ & 3.43 & $0.503^{\star \star}$ & 3.32 \\
\hline Ln (INTEN) & $-0.113^{\star *}$ & 6.54 & $-0.114^{\star \star}$ & 6.60 \\
\hline Dummy KS & -0.064 & 0.91 & -0.056 & 0.79 \\
\hline $\operatorname{Ln}(K S)$ & 0.019 & 1.14 & 0.018 & 1.05 \\
\hline $\operatorname{Ln}(S C A L E)$ & $-0.134^{\star \star}$ & 6.15 & $-0.133^{\star \star}$ & 6.11 \\
\hline Sigma & $0.454^{\star \star}$ & 22.10 & $0.457^{\star \star}$ & 21.90 \\
\hline F-Value & 10.77 & & 10.58 & \\
\hline Prob $>F$ & 0.000 & & 0.000 & \\
\hline Number of Observations & 465 & & 463 & \\
\hline
\end{tabular}

The dependent variables are the percentage of total New Product Value (or New Product Sales) contributed by Small Enterprises. Coefficients for constant terms and region dummies are not reported for brevity; ${ }^{* *} p<0.01,{ }^{*} p<0.05$. 
Figure 1

Policy Implications for the Pace and Stability of Innovation Processes

\begin{tabular}{|c|c|c|c|}
\hline & & Stability (Knowled & Ilovers / Specialization) \\
\hline & & LOW (Episodic) & HIGH (Systemic) \\
\hline Pace & $\begin{array}{c}\text { LOW } \\
\text { (Information } \\
\text { flows only after } \\
\text { negotiation) }\end{array}$ & $\begin{array}{l}\text { A. } \\
\text { Influence-Only }\end{array}$ & $\begin{array}{l}\text { B. } \\
\text { Discipline-Based }\end{array}$ \\
\hline Competition) & $\begin{array}{c}\text { HIGH } \\
\text { (Information } \\
\text { flows without } \\
\text { negotiation) }\end{array}$ & Force-Only & $\begin{array}{l}\text { D. } \\
\text { Force }+ \\
\text { Domination-Based }\end{array}$ \\
\hline
\end{tabular}

Source: Adapted from Lawrence, Winn, and Jennings (2001). 
Figure 2

Research Model

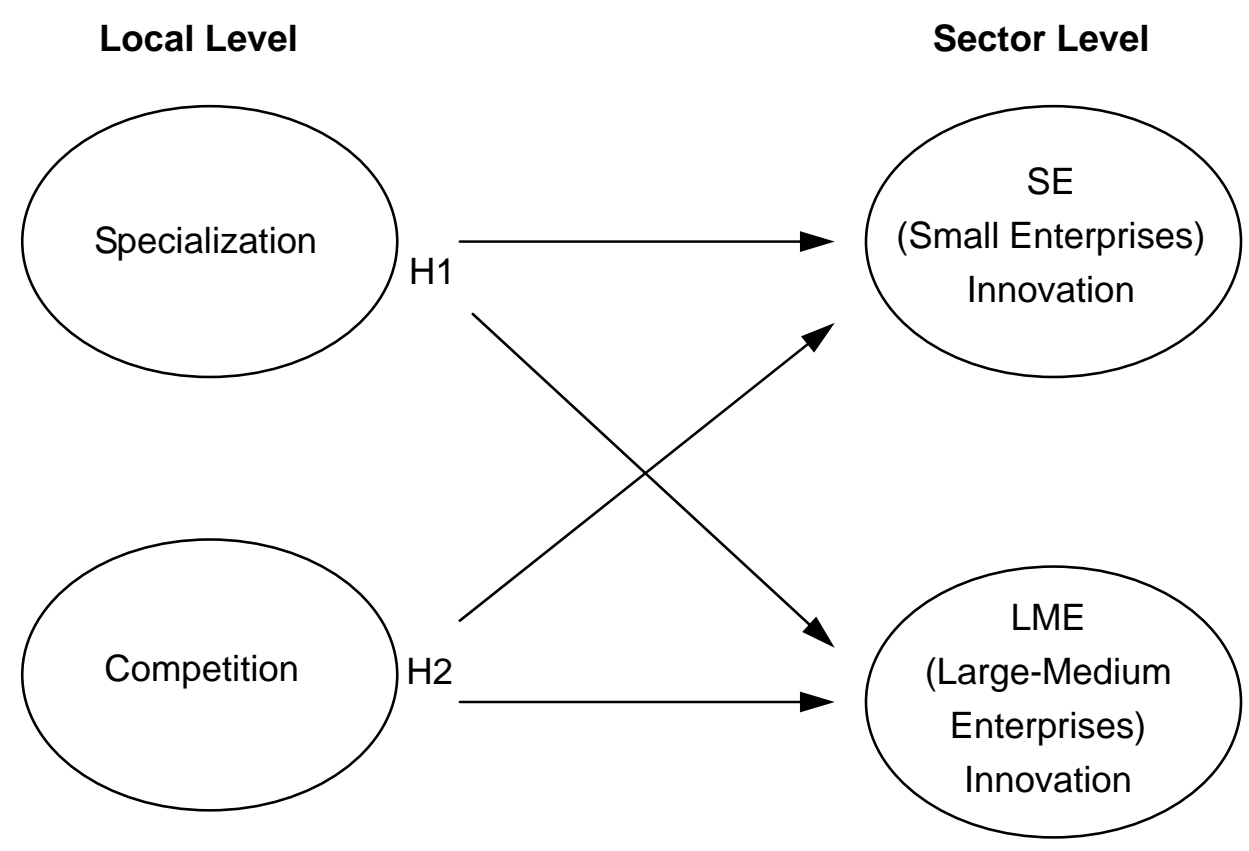




\section{Appendix}

Table A1

The Two-Digit SIC Manufacturing Sector Distribution of Observations

\begin{tabular}{llrrr}
\hline Two-Digit SIC & Name & LME & SE & Total \\
\hline 13 & Agricultural Food & 12 & 21 & 33 \\
14 & Food Manufacturing & 18 & 18 & 36 \\
15 & Beverages & 11 & 8 & 19 \\
16 & Tobacco & 5 & 1 & 6 \\
17 & Textile & 17 & 15 & 32 \\
18 & Clothing & 3 & 4 & 7 \\
19 & Leather \& Fur & 2 & 7 & 9 \\
20 & Timber \& Wood & 2 & 5 & 7 \\
21 & Furniture & 7 & 5 & 12 \\
22 & Paper Products & 7 & 6 & 13 \\
23 & Print \& Recorded Media & 5 & 6 & 11 \\
24 & Stationery & 7 & 9 & 16 \\
25 & Petroleum \& Nuclear Fuels & 6 & 4 & 10 \\
26 & Chemical Materials \& Products & 28 & 29 & 57 \\
27 & Medicine & 24 & 26 & 50 \\
28 & Fiber & 5 & 4 & 9 \\
29 & Rubber & 15 & 15 & 30 \\
30 & Plastics & 18 & 27 & 45 \\
31 & Non-metallic Mineral Products & 16 & 23 & 39 \\
32 & Ferrous Metals & 12 & 8 & 20 \\
33 & Non-ferrous Metals & 11 & 11 & 22 \\
34 & Metal Products & 39 & 49 \\
35 & General Purpose Machinery & 34 & 35 & 69 \\
36 & Special Purpose Machinery & 32 & 35 & 67 \\
37 & Transport Equipment & 21 & 20 & 41 \\
39 & Electrical Machinery & 22 & 51 \\
40 & Computers \& Electronics & 21 & 28 & 49 \\
41 & Instruments & 19 & 33 \\
42 & Artwork & 454 & 852 \\
\hline Total & & & 10 \\
\hline & & 3 & \\
\hline
\end{tabular}




\section{References}

Acs, Z. J., and D. B. Audretsch (1987). "Innovation, Market Structure and Firm Size," The Review of Economics and Statistics, 69 (4), 567-574.

Acs, Z. J., and D. B. Audretsch (1988). "Innovation in Large and Small Firms: An Empirical Analysis," American Economic Review, 78 (4), 678-690.

Acs, Z. J., D. B. Audretsch, and M. P. Feldman (1994). "R\&D Spillovers and Recipient Firm Size," The Review of Economics and Statistics, 76 (2), 336-340.

Acs, Z. J., L. Anselin, and A. Varga (2002). "Patents and Innovation Counts as Measures of Regional Production of New Knowledge," Research Policy, 31, 1069-1085.

Arrow, K. J. (1962). "Economic Welfare and the Allocation of Resources for Invention," in The Rate and Direction of Inventive Activity. Ed. R. R. Nelson. Princeton, NJ: Princeton University Press, 609-626.

Arthur, W. B. (1994). Increasing Returns and Path Dependence in the Economy. Ann Arbor, MI: University of Michigan Press.

Audretsch, D. B. (1995). Innovation and Industry Evolution. Cambridge, MA: MIT Press.

Audretsch, D. B. (2005). "The Knowledge Spillover Theory of Entrepreneurship and Economic Growth," in The Emergence of Entrepreneurial Economies, Research on Technological Innovation, Management and Policy, 9. Ed. R. R. Nelson. Princeton, NJ: Princeton University Press, 37-54.

Audretsch, D. B., and E. E. Lehmann (2005). "Does the Knowledge Spillover Theory of Entrepreneurship Hold for Regions?" Research Policy, 34, 1191-1202.

Audretsch, D. B., and M. Feldman (1996). "R\&D Spillovers and the Geography of Innovation and Production," American Economic Review, 86 (3), 630-640.

Audretsch, D. B., and M. Keilbach (2007). "The Theory of Knowledge Spillover Entrepreneurship," Journal of Management Studies, 44 (7), 1242-1254.

Audretsch, D. B., and R. Thurik (2001). "What is New about the New Economy: Sources of Growth in the Managed and Entrepreneurial Economies," Industrial and Corporate Change, 19, 795-821.

Cameron, A. C., and P. K. Trivedi (1998). Regression Analysis of Count Data. Cambridge, UK: Cambridge University Press.

Chan, D. (1998). "Functional Relations among Constructs in the Same Content Domain at Different Levels of Analysis: A Typology of Composition Models,” Journal of Applied Psychology, 83 (2), 234-246.

Cohen, W., and D. Levinthal (1989). "Innovation and Learning: Two faces of R\&D," Economic Journal, 99, 569-596.

Crépon, B., and E. Duguet (1997). "Research and Development, Competition and Innovation Pseudo-Maximum Likelihood and Simulated Maximum Likelihood Methods Applied to Count Data Models with Heterogeneity," Journal of Econometrics, 79, 355-378. 
Doh, J. P. (2000). "Entrepreneurial Privatization Strategies: Order of Entry and Local Partner Collaboration as Sources of Competitive Advantage," Academy of Management Review, 25 (3), 551-571.

Döring, T., and J. Schnellenbach (2004). "What Do We Know about Geographical Knowledge Spillovers and Regional Growth? - A Survey of the Literature,” Working Paper 14, Deutsche Bank Research.

Feldman, M. (1999). "The New Economics of Innovation, Spillovers and Agglomeration: A Review of Empirical Studies," Economics of Innovation and New Technology, 8, 5-25.

Feldman, M. P., and D. B. Audretsch (1999). "Innovation in Cities: Science-Based Diversity, Specialization and Localized Competition,” European Economic Review, 43, 409-429.

Forbes, N., and D. Wield (2000). "Managing R\&D in technology-followers," Research Policy, 29, 1095-1109.

Glaeser, E. L., H. D. Kallal, J. A. Scheinkman, and A. Shleifer (1992). "Growth in Cities," Journal of Political Economy, 100 (6), 1126-1152.

Greunz, L. (2004). "Industrial Structure and Innovation - Evidence from European Regions," Journal of Evolutionary Economics, 14, 563-592.

Grilches, Z. (1979). "Issues in Assessing the Contribution of Research and Development to Productivity Growth,” Bell Journal of Economics, 10, 92-116.

Griliches, Z. (1990). "Patent Statistics as Economic Indicators: A Survey," Journal of Economic Literature, 28 (4), 1661-1707.

Hagedoorn, J., and M. Cloodt (2003). "Measuring Innovative Performance: Is There an Advantage in Using Multiple Indicators?” Research Policy, 32, 1365-1379.

Hall, B. H., and R. H. Ziedonis (2001). "The Patent Paradox Revisited: An Empirical Study of Patenting in the US Semiconductor Industry, 1979-1995,” RAND Journal of Economics, 32 (1), 101-28.

Hall, B. H., Z. Griliches, and J. A. Hausman (1986). "Patents and R and D: Is There a Lag?" International Economic Review, 27 (2), 265-283.

Hu, A. G., and G. H. Jefferson (2006). "A Great Wall of Patents: What is behind China's Recent Patent Explosion?” Working Paper, Department of Economics, National University of Singapore.

Jacobsen, R. (1992). "The Austrian School of Strategy," Academy of Management Review, 17 (4), 782-807.

Jaffe, A. (1989). “Real Effects of Academic Research,” American Economic Review, 79 (5), 957-70.

Jaffe, A., M. Trajtenberg, and R. Henderson (1993). "Geographical Localization of Knowledge Spillovers as Evidenced by Patent Citations," Quarterly Journal of Economics, 108 (3), 577-598.

Kesidou, E. (2007). Local Knowledge Spillovers in High-Tech Clusters in Developing Countries: The Case of the Uruguayan Software Cluster. Eindhoven, Netherlands: Eindhoven University Press.

Lambert, D. (1992). "Zero-Inflated Poisson Regression, with an Application to Defects in Manufacturing," Technometrics, 34 (1), 1-14.

Lanjouw, J. O., and M. Schankerman (2004). "Patent Quality and Research Productivity: Measuring 
Innovation with Multiple Indicators," The Economic Journal, 114, 441- 465.

Lawrence, T. B., M. I. Winn, and P. D. Jennings (2001). "The Temporal Dynamics of Institutionalization," Academy of Management Review, 26 (4), 624-644.

Li, X. (2007). "Specialization, Competition and Innovation: Empirical Evidence from Chinese Large \& Medium Enterprises", Working Paper, Department of Innovation and Entrepreneurship, Tsinghua University.

Marshall, A. (1920). Principles of Economics, $8^{\text {th }}$ Ed., London: Macmillan.

Mitchell, R. K. (2003). "A Transaction Cognition Theory of Global Entrepreneurship," in Cognitive Approaches to Entrepreneurship Research. Ed. J. A. Katz, and D. Shepherd, in JAI Press: Advances in Entrepreneurship, Firm Emergence and Growth Entrepreneurship Series 6, 183-231.

Mugler, J. (2000). "The Climate for Entrepreneurship in European Countries in Transition," in The Blackwell Handbook of Entrepreneurship. Ed. D. Sexton, and H. Landstrom. Oxford, UK: Blackwell Press.

National Bureau of Statistics of China (2006). China Economic Census Yearbook 2004, Beijing, China: China Statistics Press.

Paci, R., and S. Usai (1999). "Externalities, Knowledge Spillovers and the Spatial Distribution of Innovation," Geo Journal, 49, 381-390.

Pakes, A., and Z. Griliches (1984). "Patents and R\&D at the Firm Level: A First Look," in NBER Conference Report D. Ed. Z. Griliches. Chicago: University of Chicago Press, 55-72.

Peng, M. W. (2001). "How Entrepreneurs Create Wealth in Transition Economies," Academy of Management Executive, 15 (1), 95-108.

Porter, M. E. (1990). The Competitive Advantages of Nations. New York: Free Press.

Porter, M. E. (1998). "Clusters and the New Economics of Competition," Harvard Business Review, 76 (6), 77-90.

Rumelt, R. P. (1987). "Theory, Strategy, and Entrepreneurship," in The Competitive Challenge: Strategies for Industrial Innovation and Renewal. Ed. D. J. Teece. Cambridge, MA: Ballinger, 137-158.

Shaver, J. M., and F. Flyer (2000). "Agglomeration Economics, Firm Heterogeneity, and Foreign Direct Investment in the United States," Strategic Management Journal, 21, 1175-1193.

Tan, J. (2001). "Innovation and Risk-Taking in a Transitional Economy: A Comparative Study of Chinese Managers and Entrepreneurs," Journal of Business Venturing, 16, 359-376.

Tan, J. (2006). "Growth of Industry Clusters and Innovation: Lessons from Beijing Zhongguancun Science Park," Journal of Business Venturing, 21, 827-850.

Tan, J. (2007). "Phase Transitions and Emergence of Entrepreneurship: The Transformation of Chinese SOEs over Time," Journal of Business Venturing, 22, 77-96.

Tan, J. and D. Tan (2005). "Environment-Strategy Co-Evolution and Co-Alignment: A Staged Model of Chinese SOEs under Transition,” Strategic Management Journal, 26, 141-157. 
Thornhill, S. (2006). "Knowledge, Innovation and Firm Performance in High- and Low- Technology Regimes,” Journal of Business Venturing, 21, 687-703.

van der Panne, G. (2004). "Agglomeration Externalities: Marshall versus Jacobs," Journal of Evolutionary Economics, 14, 593-604.

Venkataraman, S. (1997). "The Distinctive Domain of Entrepreneurship Research," in Advances in Entrepreneurship, Firm Emergence, and Growth. Ed. J. Katz and R. Brockhaus. Greenwich, CT: JAI Press, 119-138.

Vuong, Q. H. (1989). "Likelihood Ratio Tests for Model Selection and Non-Nested Hypotheses," Econometrica, 57 (2), 307-33.

Welsh, J. A. and J. F. White (1981). "A Small Business is not a Little Big Business”, Harvard Business Review, 59 (4), 18-32.

Winkelmann, R. (2000). Econometric Analysis of Count Data. Berlin, Germany: Springer-Verlag.

Winter, S. G. (1984). "Schumpeterian Competition in Alternative Technological Regimes," Journal of Economic Behavior and Organization, 5 (3/4), 287-320.

Zajac, E., M. Kraatz, and R. Bresser (2000). "Modeling the Dynamics of Strategic Fit: A Normative Approach to Strategic Change," Strategic Management Journal, 21, 429-454. 